\title{
Transitional Women in the Transnational Era: Female Voices through Art
}

\author{
SILVIA PELLICER-ORTÍN \\ Dpto. Filología Inglesa y Alemana, Facultad de Educación, Universidad de \\ Zaragoza, Calle Pedro Cerbuna, 12. 50009 Zaragoza, Spain. \\ Email: spellice@unizar.es
}

\begin{abstract}
This article supports the belief that transnational and glocal mechanisms have drastically affected identity and memory formation processes; thus, very diverse memories regarding complex episodes of migration or trauma are currently regarded as connected through multidirectional and cross-cultural patterns. Drawing on the fields of Trauma and Memory Studies, which consider the therapeutic role of art to represent and abreact troubled individual and collective experiences, the new hybrid identities born from this exchange and relationality have proved to demand new forms of representation. In particular, numerous groups of transitional women have recently fostered transnational engagements of womanhood through their creative works. Thus, some contemporary examples will be provided to show how art can be an empowering tool for contemporary transitional women to acquire a voice as well as a promoter of empathy for the modern glocal subject.
\end{abstract}

\section{A Glocal Context}

When one attempts to define the convoluted times our societies are going through, the increasingly powerful conception of the world as an integrated global place usually comes to the fore. The decline of national sovereignty characterized the turn of the century, and it is now very difficult to imagine our environments without alluding to this global context. Thus, globalization has come to be defined as 'the intensification of a consciousness of the world as a whole'. ${ }^{1}$ Following Stephen Castles and Mark J. Miller in their pioneering study on The Age of Migration, 'the most striking features of globalization are the growth of cross-border flows of various kinds, including investment, trade, cultural products, ideas and people; and the proliferation of transnational networks with nodes of control in multiple locations'. ${ }^{2}$ Drawing on this, other contemporary scholars such as Susan Friedman have identified a shift from nation-based paradigms to 'transnational models emphasizing the global space of ongoing travel and transcontinental connection ${ }^{3}$ - a phenomenon which has 
awakened a 'new global consciousness' whose 'fundamental changes are [still] to occur'. ${ }^{4}$ In fact, Castles and Miller also point out that globalization has resulted in 'increased transnationalism: behaviour or institutions which simultaneously affect more than one state' (Ref. 2, p. 1). In keeping with this, Spanish philosopher Rosa María Rodríguez Magda has contended that the constant presence of flux and connectivity in our present Information Society has fostered an emerging process of totality that, rather than hierarchical or pyramidal, follows a network-like mode, which is devoid of any clear organization or hegemonic centre. Thus, this interconnected and unstable reality appears to beg for a similarly 'transborder' mode of thinking, ${ }^{5}$ which may be capable of responding to the emerging demands of this era of swift transformations.

Notwithstanding that our world has increasingly become an interconnected fluid space, an opposite tendency seems to have developed pari passu these transnational processes: the growing number of socio-political movements claiming for the visibility of local entities within this global background. An increasing number of pressure groups have appeared, demanding the singularity of their particular contexts and looking for local versions of history and minority interpretations of our unstable reality. This phenomenon has been alluded to by sociologist Myra Marx Ferree, when she describes as striking the present intersection of the global with the local, and the expansion of popular, decentralized, and democratic forms of interpreting and responding to the top-down challenges posed by a world economy'. ${ }^{6}$

Considering this context, one of the main aims of this article is to link these processes of glocalization ${ }^{7}$ to the way they affect individual and collective identity and memory formation processes. Drawing on the fields of Trauma, Memory and Women's Studies, this article seeks to demonstrate that artistic practices may offer fruitful sites where contradictory, and even traumatic, events shaping the identity of the transnational subject in general, and the transitional female subject in particular, may be exposed. Thus, art is expected to emerge as a productive mechanism for some minorities to voice their alienating experiences and claim their inclusion into public discourses. I will provide examples from diverse artistic realms in order to show that art stands for a memory and identity vehicle that can force contemporary audiences to leave their comfort zones and empathetically witness experiences of marginalization and displacement through female transnational eyes.

\section{Multidirectional and Artistic Connections}

In 2009, historian Michael Rothberg developed the concept of multidirectional memory, suggesting that we should 'consider memory as multidirectional: as subject to ongoing negotiation, cross-referencing, and borrowing; as productive and not privative'. ${ }^{8}$ In the same vein, Max Silverman has recently claimed that 'palimpsestic memory' is 'a ceaseless process of straddling and superimposition of elements, [where] memory traces overlap, intersect and are transformed'. 9 These new-fangled visions of memory point at the way in which very diverse individual and collective memories of complex episodes of migration and displacement, and even trauma and 
war, can be regarded as interrelated, mainly when they have caused unfair suffering to minority groups. ${ }^{10}$

Drawing on this, the contemporary phenomenon of the spatialization of memory should also be considered. As Susannah Radstone has put it, the attention to cultural memory as process has involved 'the spatial tracking of memory as a significant aspect of what has suggestively been termed memory on the move'. ${ }^{11}$ And Katharina Schramm has claimed that 'the process of identification of memory with place [...] implies the complex entanglement of procedures of remembering, forgetting and the production of counter-memories'. ${ }^{12}$ The idea of 'travelling memories ${ }^{13}$ has thus come to the fore, and Memory Studies have evolved towards the analysis of memory cultural dynamics, emphasizing 'its inter- and transmedial dimensions' (Ref. 11, p. 110). In the so-called 'Age of Migration', ${ }^{2}$ memories have proved to travel across space and time; demonstrating that a trans- and cross-cultural view of memory may offer new insights for understanding current transcultural dynamics. Although immigrants are not unique in this, as 'multiple identities are becoming an almost general characteristic of the people of late modern societies' (Ref. 2, p. 289), this identity and memory flow can be particularly observed in immigrant communities. They are compelled 'to have multilayered socio-cultural identities, which are constantly in a state of transition and renegotiation', and they 'develop a consciousness of their transcultural position, which is reflected not only in their artistic and cultural work, but also in social and political action' (Ref. 2, p. 289).

Considering these notions, the next question would be: What does art have to do with all this? As sociologist Magie O'Neill, drawing on the aesthetic theories of wellknown modern philosophers Theodor Adorno ${ }^{14}$ and Walter Benjamin, ${ }^{15}$ has stated:

for critical theorists and cultural sociologists the relationship of art to society is one of mediation. Art is a 'feeling form' created in the tension between sensuous knowing, the playfulness and creativity of the artist and the historically given techniques and means of production. Art is a social product not just a reflection on its social origins and it manifests its own specificity - it is constitutive. Art makes visible experiences, hopes, ideas; it is a reflective space and socially it brings something new into the world - it contributes to knowledge and understanding. ${ }^{16}$

Along with this, I would contend that, just as new identities have emerged out of this 'transnational revolution that is reshaping societies and politics around the globe' (Ref. 2, p. 7), this new relationality has demanded new forms of representation. As exposed by Castles and Miller, 'in the context of globalization, culture, identity and community often serve as a focus of resistance to centralizing and homogenizing forces. [...] For ethnic minorities, culture plays a key role as a source of identity and as a focus for resistance to exclusion and discrimination' (Ref. 2, p. 39). This multidirectional outlook on memory and identity has also brought to light the prevalent idea, mainly in the fields of literary and cultural studies, that our individual and collective identities are artificially constructed in the public sphere, defining the social attitudes, policies and ideologies that sustain our societies. In Stuart Hall's words, 'we should think of identity as a 'production', which is never complete, always in process, and always constituted within, not outside, representation' ${ }^{17}$ 
In this sense, art becomes the sphere where many of these transnational, hybrid, and often marginalized, identities may be negotiated since, as psychiatrist Sandra L. Bloom argues, artistic manifestations satisfy the inherent human need to reintegrate the fragmented psyche and achieve psychological wholeness when some shocking experience has damaged the protective mechanisms of the psyche. ${ }^{18}$ She considers that the eternal question of 'what are the arts for?' (Ref. 18, p. 198) would be answered if we were able to see artistic manifestations as part of the human need to share difficult experiences with the community and as tools to create links between the individual suffering and the rest of the society. In fact, many of those minority groups which had been previously excluded from hegemonic historical discourses owing to class, gender, racial, and religious factors (Ref. 17, p. 229) have progressively re-constructed their fragmented or silenced stories through artistic practices in the last few decades. Their "counter-stories ${ }^{19}$ have started to defy long-established totalitarian versions of history, making good the contention that art has a crucial role in the representation and abreaction of troubled individual and collective experiences. ${ }^{20}$

\section{Trauma and Memory Studies}

The fields of Trauma and Memory Studies - which emerged in the 1990s and reached their climax by the turn of the century - have worked on the premise that diverse acts of storytelling can contribute to the negotiation of complex identities, and even the healing of traumatized individual or collective memories. Well-known psychoanalytical concepts such as Sigmund Freud's 'talking cure', ${ }^{21}$ or Pierre Janet's ${ }^{22}$ and Carl Jung's ${ }^{23}$ certainty that the healing of individuals and communities begins when they are able to transform traumatic events into a coherent narrative are traditional examples of the view that the main step for the assimilation of painful past events is to narrativize these experiences. More contemporary literary critics have coined notions such as 'scriptotherapy' to name 'the process of writing out and writing through traumatic experience in the mode of therapeutic re-enactment'. ${ }^{24}$

A great variety of trauma critics ${ }^{25}$ concur in asserting that narrative may offer a unique space to verbalize, assimilate and heal conflicting experiences at a variety of levels: for the individual artists behind these narratives; for the minor groups their narrations stand for; and for the readers who enter an empathic relationship with the texts, ${ }^{26}$ which allows them to see the pain of 'Others' and be implicated in their alien experiences. As literary scholar Susana Onega has argued, central to this is Levinas' ethics of alterity ${ }^{27}$ with

its demand that we make an ethical move away from the I towards the 'absolute Other', [... which] produces a crisis of identity as its sets our ego into question and confronts it with that which escapes our cognitive powers. The achievement of this ethical goal depends on our capacity for abnegation and the fostering of affects such as love and empathy. ${ }^{28}$

Artistic practices lead their audiences to look at the face of diasporic characters, transnational images, dystopian spaces; extracting from them various ethical lessons that can be extrapolated to the social realities outside the cultural artefact. In the 
specific case of literary works, Derek Attridge has defended his belief that literature is singular because it responds more vividly to our ethical drives than philosophy, politics or history on the grounds that we can experience literary works not as objects but as events in our lives which exceed our rational accounting. ${ }^{29}$ These arguments have recently been fostered by French critic Jean-Michel Ganteau, who explains that literary works have the power to create a world that promotes 'a vision of individuals as interdependent and of humanity as radically relational'. 30

In addition to this, it should be remembered that the unprecedented visibility of social, ethnic, religious and/or sexual minorities in present-day narratives begs for the consideration of a phenomenon whose origins go back to the change of worldview that took place in the Western world in the late 1960s and 1970s. ${ }^{31}$ As Onega further explains, the epistemological crisis that characterized this time brought about 'a generalised loss of faith in humanist values and the widespread demands for engagement and commitment by the new pacifist, anti-militarist, feminist and "green" political options then emerging'. And, although their interests were very different, 'these new ideological factions shared a sustained critique of totalizing "master narratives" that greatly contributed to opening up new spaces for the expression of the ideologies of the political, sexual, ethnical and religious margins of patriarchy' (Ref. 28, p. 496). This change brought about a number of socio-cultural and political changes across the Western world, from the passing of laws to protect minorities' rights to the redress of balance in the definition of "self" and "other". Within the particular context of British art and literature, Philip Tew has shown that, since the 1970s, British fiction has "become more "multi cultural" or ethnically diverse in authors and subject matter', ${ }^{32}$ and Ganteau has pointed out that British writers have been increasingly concerned with creating fictional spaces where minority voices manage to problematize their vulnerable positions. ${ }^{33}$

Moreover, just as writing practices have provided adequate sites to speak out previously unheard experiences of marginalization and abuse, the propagation of these narratives has increased society's interest in these stories. Ann Heilmann and Mark Llewellyn have maintained that there has been an increasing growth in the "new histories of women, non-Western cultures, ethnic, racial and sexual minorities since the late 1960s', which 'has prompted a change in educational practice as well as public perception'. ${ }^{34}$ Following Nigerian writer Chinua Achebe, a process of 're-storying' those peoples who had been kept silent by all kinds of dispossession was deemed necessary at the turn of the millennium so as to achieve 'a balance of stories among the world's peoples'. ${ }^{35}$ A process which may be said to have reached its climax at the beginning of the twenty-first century, the moment when a vast number of thinkers have become aware of the ethical need to transcend the dominant Eurocentric perspective and deconstruct the 'West/non-West binary that is at the root of Eurocentric thinking' if we want to enter into a generative transnational dialogue across the globe. ${ }^{36}$

\section{Women in Search of a Voice}

When talking about underrepresented groups, women unavoidably come to the fore as they have found it difficult to publicly voice their versions of history for centuries, 
while the notion of womanhood has traditionally been modelled by men. ${ }^{37}$ Now that the various waves of feminism have gone by, it is generally accepted that sexuality and gender are social constructs and that the relationship between men and women has conventionally been embedded in power structures, turning gender into a socio-cultural conception constructed on biological, economic and cultural grounds. $^{38}$

For their part, women have been voicing their neglected versions of history through all sorts of artistic practices for decades. Since Virginia Woolf's time, many women artists from different generations have explored the contradictions embodied in their complex identities as well as the possibilities to challenge assumed versions of femaleness in their works. Going back to the origins of the second wave of feminism in the 1970s, literary critic Patricia Waugh already maintained that:

feminists turned to art and literature as a means of working through such [social and identity] contradictions, [...]. Feminist writers and critics embraced the utopian potential of art, its capacity not only to defamiliarise and expose sources of inequality, but also to imagine and construct worlds elsewhere. ${ }^{39}$

This is a task that has been carried out on a global scale by women artists from very diverse contexts, creating spaces where the public and the private, the individual and the collective, the personal and the historical can establish an interactive dialogue. ${ }^{40}$ For instance, the current generation of Anglophone women writers - including such well-known authors as A.S. Byatt, Margaret Atwood, Joyce Carol Oates, and Alice Walker - have been very much aware of the need to deconstruct prevailing female stereotypes by creating resisting narratives that call attention to the subtle chauvinist mechanisms that subjugate women on a daily basis, among which the use of language deserves pride of place.

This is even more compelling for the numerous groups of immigrant women that have felt as alien Others at a variety of levels: as Others within the new languages, cultures and histories that they have needed to incorporate into their own; and as Others within patriarchal structures that have traditionally oppressed and subjugated them. Following Castlers and Miller, one of the main features of the 'Age of Migration' is the 'feminization of migration', since women have come to 'play a significant role in all regions and most (though not all) types of migration'. Although, 'in the past, most labour migrations and many refugee movements were male dominated, [...] since the 1960s, women have played a major role in labour migration. [... thus] awareness of the specificity of women in contemporary migrations has grown' (Ref. 2, p. 9). In keeping with this, at the very beginning of the twenty-first century, sociologist Pierrette Hondagneu-Sotelo argued that: 'we now have a clear understanding that migration is gendered and that gender relations change with migration processes'. ${ }^{41}$ Therefore, the gendered outlook on migration deserves further study since, as exposed on the Open Democracy website, 'studying transnationalism, meaning that migrants are seen as representatives of a more globalized world, also asks for a gendered approach to the subject, since women and men experience immigration and citizenship in different ways'. ${ }^{2}$ 
In this context, the prefix trans- can shed some light on this field. Following Leigh Gilmore and Elizabeth Marshall, transnational engagements of womanhood have become powerful mechanisms to foster larger claims for justice and human rights as well as to provide feminine critiques of race and gender. ${ }^{43}$ By 2005, when M. Jacqui Alexander's Pedagogies of Crossing was published, she distinctly defined the field she was working on as 'transnational', coining the ideology of 'transnational feminism' which evoked international gatherings, anti-imperial and decolonial thought, and Postcolonial Studies - mainly through the influence of postcolonial and feminist critic Gayatri Spivak. ${ }^{44}$ Drawing on the recent ideas exposed by Maylei Blackwell, Laura Briggs and Mignonette Chiu, the 'transnational' here names an emergent post-1960s immigration reform axis of difference, which attempted to centre 'new immigrants' along with the new forms of globalization and its resistance. ${ }^{45}$ Yet their claim for 'a liminal third space of politics, spirituality, and nationality' (Ref. 45, p. 2) is not drastically new as, for instance, Gloria Anzaldúa's Borderlands epistemology broke new ground in the 1980s, when she argued for the metaphorical in-betweenness of the Chicana identity in the USA. $^{46}$ These are some of the claims that have inspired contemporary transnational feminists in order to advocate for women's crossing of international borders in a common fight for global rights. Thus, within the field of Women's Studies, the transnational may function as an analytical tool to see how global processes, such as migration, cross international borders and affect women's lives, whereas it can also provide an invigorated prism from which women's art works can be examined.

\section{A Journey through Transitional Women's Art}

Drawing on the belief that, for many transitional and transnational women, artistic manifestations have become fruitful sites to 'give expression to the voiceless or to that which could not make itself heard before', ${ }^{47}$ I will provide diverse examples of the way in which art may act as an empowering tool for contemporary women to reconcile their fragmented selves, find a place in the immigrant societies, subvert gender stereotypes, and try to define their feminine selves in both local and global interrelated systems. Just as pioneering feminists Grewal and Kaplan stated in the 1990s that 'we must devise ways in which feminist practices can work against ever-changing, patriarchal collaborations all over the globe', ${ }^{48}$ some of the works analysed will emerge as multidirectional sites where inequality and alienation can be negotiated and denounced. Yet most of the examples selected come from an Anglophone context since English often becomes the main instrument of artistic expression for these minorities if they want to disseminate their political ideas more effectively and become known to a major audience.

Regarding the field of literary fiction, there is a vast plethora of narratives depicting the difficult experiences that lie behind the diasporic movements undergone by women in the last few decades: Cuban-American transitions, as can be seen in Cristina García's Dreaming in Cuban (1992) and Loida Martiza Pérez's Geographies of Home (1999); Asian-American relations, in Gish Jen's Mona and the Promised Land (1997) or Amy Tan's Bonesetter's Daughter (2001); African-American stories of generational oppression, such as Alice Walker's The Color Purple (1982), Toni Morrison's Beloved (1987) 
and, more recently, Phyllis Alesia Perry's A Sunday in June (2004) and Aminatta Forna's The Memory of Love (2011); the British-Caribbean legacy, as happens in Zadie Smith's White Teeth (2000) or Shani Mootoo's Cereus Blooms at Night (1996); the conflictive past of Native-American cultures, as illustrated in Louise Erdrich's The Round House (2012); British-Indian legacies, characterizing Meena Alexander's Nampally Road (1991) and Anita Desai's Baumgartner's Bombay (1988), and so forth. In fact, the list of writers and works showing the multiple ways in which previous ideas of nation and identity have been challenged by migration and mobility could multiply by adding more complex global and hyphenated identities, which seem to pervade the twenty-first century literary panorama. ${ }^{49}$

In very general terms, most of these narratives share a common use of spatial metaphors that evoke the dislocation of the female transnational subject; images of hybridity symbolizing the experiences of in-betweenness undergone by the protagonists; spiritual and physical journeys to their homelands; and personal quests for independence and liberation. Furthermore, in most of them, the boundaries between the fictional characters represented and the real authors outside the text are blurred, since these writers manage to provide the oppressed characters represented with a more stable sense of identity throughout the narrative while they become active subjects in the public global sphere through these imaginative acts of writing.

A very illustrative example of this is Beloved, Nobel-prize winner Toni Morrison's 1987 rewrite of the traumatic history of a whole generation of black slave women, a history that shows the contradictory urges both to transmit and silence the painful memories of these women's past. Morrison textualizes the body of the main character, Sethe, in order to represent the collective damaged identity of many Black women enduring diaspora, slavery and abuse across time. Sethe's scarred body symbolizes the hurt identity of many other women likewise defined by their scars, symbolizing their horrible past. However, as may be observed in the popular passage in the novel where Sethe bares her hurt body in front of Paul D, Sethe's scars, simulating the shape of a tree, finally sublimate a site of pain into one of beauty and growth, highlighting the possibility of healing across generations. ${ }^{50}$ Therefore, although 'Morrison leaves it to the reader to decide whether this revision of a nineteenth-century slave narrative will result in liberation in the twenty-first century', what stands clear is that in the late 1980s Morrison already trusted the possibilities offered by literature to transcend the oppressed female body. ${ }^{51}$

A more recent instance comes from Anglo-Caribbean writer Zadie Smith's White Teeth. Set against the assumed multicultural background of contemporary London, this novel deconstructs some predominant and stereotypical ideas of race, nation, assimilation and even religious fundamentalism in an attempt to voice the difficulties that hybrid subjects encounter in reactionary societies such as the British one. These critical thoughts are recurrently voiced by the different characters, as when Samad tells Irie about his feelings of unbelonging after migrating to England:

These days, it feels to me like you make a devil's pact when you walk into this country. You hand over your passport at the check-in, you get stamped, you want to 
make a little money, get yourself started... but you mean to go back! Who would want to stay? [...] In a place where you are never welcomed, only tolerated. ${ }^{52}$

Or when Irie confronts the unreliable meaning of homeland: "no fiction, no myths, no lies, no tangled webs - this is how Irie imagined her homeland. Because homeland is one of the magical fantasy words like unicorn and soul and infinity that have now passed into language' (Ref. 52, p. 402, emphasis added). In these two examples, the ideas of belonging and homeland appear to be idealistic utopias in contrast to the reality of the hostile land where hybrid characters find it very hard to accommodate. In this way, Smith, the daughter of a Jamaican immigrant woman, problematizes the multidirectional paths of memory and identity that lead many current female subjects to feel in-between different worlds and cultures.

Recent decades have also witnessed the proliferation of life-writing. The formal distinctions between fiction, autobiography and testimonial literature, together with the role of the writer in these kinds of narrations, has created many dilemmas for contemporary critics, especially with the recent boom of hybrid autobiographical genres. ${ }^{53}$ In fact, many of these genres have proved to deal with problematic aspects concerning the narrativization of difficult life experiences, which have given way to new experimental features characterizing them: the predominance of individual and local versions of history, the fusion of literary and non-literary genres, the construction of embedded narratives, and the use of self- and meta-reflexive comments on trauma (Ref. 53, pp. 14-19).

Some relevant instances of these limit-case autobiographies are found in those contemporary Anglophone Jewish women writers who have lately published a vast amount of autobiographical works in order to reconcile themselves with their ancestors' land as well as their adoptive homes, to put together the fragmented pieces of their shattered identities, and to come to terms with what it means to be a Jewish woman in today's world. ${ }^{54}$ In The War After, ${ }^{55}$ Anne Karpf mixes testimonial, autobiographical and historical elements along with interviews, letters, journalistic reports and trauma theory. Her autobiography acts as the narrative device to explore her parents' past as Holocaust survivors, the collective history of the Second World War and the Nazi regime, the traumatic process of transgenerational transmission of trauma inherited by many subsequent generations of Holocaust survivors, like Karpf herself, as well as the personal story recounting her own journey to the family homeland (Poland). In fact, she acknowledged the uniqueness of this work when she commented:

I'll never write another book like The War After - of this, I'm certain. My family memoir recounts the experiences of my parents [...]. But it's also my own, intensely personal story, about the impact of the Holocaust on the generations born after. ${ }^{56}$

These ideas confirm the view that writing can become an act of scriptotherapy for those subjects that need to speak out lived or inherited painful experiences.

Another example may be observed with literary critic, musician and writer Michelene Wandor, also of British-Jewish origin, as in one of her literary essays she explains her marginal relationship - and by extension that of other migrant Jewish 
women writers - with the centre, and how language (English in this case) has played a crucial role in giving expression to her multifaceted identity as well as re-defining her identity boundaries between the centre and the margins. That is to say, the use of English as a non-native language has usually double-sided implications for most female transnational artists. English is, on the one hand, a foreign language alienating these subjects' original selves but, on the other, it provides them with the tools to make their message known to the world, offering them the opportunity to move from the margins to the centre. As she explains in another essay:

the Centre for each of us is our dominant language and the culture to which it belongs. The Edges from which - in my case - I relate to them - are those of woman, feminist, socialist, playwright, poet, novelist, and a host of others. These are not merely fragmentations, but segmented sources of both my histories and my literary/ aesthetic/political interests, and all these coalesce round this main expressive language of English. ${ }^{57}$

These ideas echo the recurrent discussion in the fields of Women's and Diaspora Studies on the problematic relationship between the centre and the margins. Following Caren Kaplan's feminist theories (1987), the fact of living on the edge may provide minor writers with the capacity to focus their attention on the centre as well as the margins. As a matter of fact, Kaplan believes that many liminal autobiographical works written by women create anew ideas that are embodied by the liminal writers mentioned so far: ${ }^{58}$

space in the imagination which allows for the inside, the outside, and the liminal elements of inbetween. [...] It points towards a rewriting of the connections between different parts of the self in order to make a world of possibilities out of the experience of displacement

Film and documentaries show a similar situation. Many films representing the greatest migratory movements of the twentieth century, mainly those caused by the Second World War and after, focus on female perspectives on these events. Barbra Streisand's Yentl (1983), an American romantic musical drama based on Leah Napolin and Isaac Bashevis Singer's play, and originally based on Singer's short story 'Yentl the Yeshiva Boy' (1983), relates the adventures of a Jewish girl in Poland who dresses and lives like a man so that she can receive an education in Talmudic Law. Éva Gardos' An American Rhapsody (2001), depicts a Hungarian girl struggling to find her place in the world when reunited with her parents in the USA many years after she was left behind during the Communist regime of the 1950s. Yamina Benguigui's Sunday God Willing (2001) revolves around the life of an Algerian immigrant woman in France and focuses on her family's experience after migration along with the struggles for autonomy that Algerian women face today. Regardless of their particular contexts, these films aim to make the complex identity tensions endured by these hybrid women visible. Also, they seem to embody Castles and Miller's claim for the politicization of culture in most countries affected by immigration (Ref. 2, p. 40). Thus, these artistic forms become political weapons in their attempts to produce cultural symbols that allow these female minorities to progressively penetrate the dominating hegemonic societies. 
As far as the documentary form goes, a very interesting initiative was launched by the New York Women in Film \& Television organization in 2015 to produce a screening series for their Cultural Immigrant Initiative, 'Immigrant Women: Sharing Our Voice Through Film', whose main objective was to disseminate NYC immigrant stories made by women film-makers. In 'Judith: Portrait of a Street Vendor', Pirani journeys into the daily life of Judith, a street seller from Guatemala who lives and works in New York. She exposes this woman's daily struggles in the city streets and her hopes as an immigrant worker, a mother, and an activist. Therefore, documentaries like this one illustrate how ethnic and gendered minority groups try to gain power by making their experiences visible in the country of immigration (Ref. 2, p. 40). Nevertheless, there is a group of women that deserves further attention, as it has been particularly productive in the creation of texts where their conflictive relationships with the notion of the frontier and the limitations imposed on them by the patriarchal system are exposed: the Chicana film-makers. A great instance is the work carried out by Linda Garcia Merchant in her acclaimed Las Mujeres de la Caucus Chicana (2007) which, drawing on the feminist Chicano movements of the 1960s and 1970s, narrates the stories of six Latinas who founded the National Women's Political Caucus. Some of the key aims of this documentary are to give a voice to all those Latina sisters who fought for their liberation across the nation and inspire the current generations to go for transnational engagements of womanhood.

Graphic novels have also become the site where women manage to symbolize their hybrid identities. In Graphic Details: Confessional Comics by Jewish Women, ${ }^{59}$ Sarah Lightman offers intimate and subjective details of the lives of 18 Jewish women artists, who in their autobiographical comics, bare all their identity tensions, as Jewish, women, descendants of immigrants, and/or survivors, yet these tensions also resonate beyond self, gender and ethnicity. Another relevant, and quite different, example is Gwendolyn Willow Wilson and Adrian Alphona's Ms. Marvel No Normal, ${ }^{60}$ where the protagonist Kamala, a second generation Pakistani immigrant raised in the USA, acquires supernatural powers, something the media do not usually associate with a Muslim background, which she uses to save people while wearing patriotic American colours. By deconstructing deeply-rooted stereotypes, this character may have the power to change people's assumptions about Islam and Pakistani culture. These two examples show that graphic novels can be fruitful platforms to depict transitionality and transnationality from multifarious female perspectives.

Other visual arts also offer very fruitful examples of how contemporary women use their imagination to reinvent themselves by trespassing boundaries and trying to connect, regardless of the peculiarities of their local contexts. For instance, the photographical exhibition 'Miradas de Iberoamerica', organized by the 'Programa de la Cooperación Iberoamericana IBER-RUTAS' in 2015, focused on the issue of gender and immigration to promote the need to defend human rights and equality among South-American female immigrants in Spain. The winner, Lena Mucha, was a German woman who embodied the transnational feminist idea that women can connect across languages and cultures in denouncing their difficult experiences. The photograph 'Rosalba' gives visibility to a South-American woman, who would not have found a 
space of her own if it had not been because of this European photographer. A similar project was set up in Berlin by the association 'Migrantas'. Working with public urban spaces as its platform, Migrantas aims to make visible the feelings of those women who have left their country and now live in a new one. As they explain on their website:

migrant women and their experiences remain often invisible to the majority of our society. Migrantas works with issues of migration, identity and intercultural dialogue. Their work incorporates tools from the visual arts, graphic design and social sciences. [...] The resulting drawings are then condensed into pictograms and distributed in public spaces. ${ }^{61}$

To sum up, all these initiatives show that art provides transitional women with the tools to represent themselves; which would plead for the therapeutic role of art. As psychiatrists Dori Laub and Podell put it, 'imaginative acts arise in one's attempt to "know" the traumatic events that confront him. [...] Art aids survival (as well as recovery) by widening one's vision and offering alternative perspectives and ways of seeing things'. ${ }^{62}$ Applying these notions to these women's creations, the use of visual and textual platforms has allowed these women to deal with the intricate experiences of migration and post-migration by representing their own selves from manifold perspectives while projecting their complex images onto the new society.

\section{Conclusion: Artistic Bridges}

Several challenges have been hinted at in this study. To begin with, educational and political institutions should work hand in hand to foster a deeper feeling of empathy across the nations for global citizens to be open to all these alternative sets of origin stories and to the complicated ways diverse people are situated or constructed by their nations. This would destabilize the static notion of the nation state and open the debate on what the notion of transnational may mean for the modern diasporic subject, particularly the female one. Drawing on this, an invigorated approach to transnational feminism should not forget about previous critical discourses, such as Postcolonialism, in order to prevent totalizing forces from absorbing these minorities' stories. On the contrary, a more global outlook on feminism should manage to show the connections in the lives of those multifarious women on the move, but always maintaining the unique value of their singular stories. As feminist critic Mari Tripp argues, although it tends to be generally accepted that

ideas regarding the emancipation of women have spread from the West outward into other parts of the world, [...] the influences have always been multidirectional, and the current consensus is a product of parallel feminist movements globally that have learned from one another but have often had quite independent trajectories and sources of movement. ${ }^{63}$

In the end, attention must be paid to the power relations that give voice to some groups while others continue to be silenced. While I have focused on works created by 'hyphenated' writers that have adopted English as their means of expression, or by women whose difficult experiences have been translated into mainstream cultural 
forms, other subjugated voices still remain silent due to political, economic, ideological or religious interests. Thus, it is the role of cultural critics to deconstruct these allegedly fixed biological or cultural characteristics through the choice of their analytical corpus, and to develop a multidirectional perspective on these creations.

Still, the use of art as an empowering site for migrant women in particular, and for our glocal societies in general, has been sufficiently demonstrated, I hope. If contemporary phenomena such as globalization, transnationalism and migratory movements characterize how today's subjects perceive themselves and their relationships, the multifarious cultural productions discussed unveil that the submission not only of women but also of other minorities remains an issue. Thus, art can offer new prisms from which to re-approach these problematic experiences. The works briefly discussed here demonstrate that art provides a fruitful platform for including the silenced minorities in the public sphere and thus it should acquire a more socio-political role instead of the abstract role that has been assigned to it by the capitalized globalized systems. As recently-deceased British writer John Berger fiercely maintained:

art has often judged the judges, pleaded revenge to the innocent and shown to the future what the past has suffered, so that it has never been forgotten. [...] Art sometimes runs like a rumour and a legend because it makes sense of what life's brutalities cannot, a sense that unites us, for it is inseparable from a justice at last. Art, when it functions like this, becomes a meeting-place of the invisible, the irreducible, the enduring, guts and honour. ${ }^{64}$

This amounts to a plea for the capacity of art to foster empathic bonds among societies and to look at those Others' eyes whose troubling experiences ultimately become part of our glocal self. In fact, these ideas would support Silverman's view that art works are better suited than historical or sociological works to make visible the complex interaction of times and sites in current memory and identity frictions, since an essential characteristic of imaginative works is to 'blur the frontiers between the conscious and the unconscious, the present and the past, and the personal and the collective' (Ref. 9, pp. 28-29). However, instead of blur, I would use the verb bridge, as art offers a bridge between cultures, times, religions and languages - a bridge that, at this very moment, many brave women may be just crossing in the hope of an invigorated future.

\section{Acknowledgements}

The research carried out for the writing of this article was part of a project financed by the Spanish Ministry of Economy and Competitiveness (MINECO) (code FFI201565775-P). The author is also grateful for the support of the Government of Aragón and the European Social Fund (ESF) (code H05).

\section{References and Notes}

1. R. Robertson (1992) Globalization: Social Theory and Global Culture (London, Thousand Oaks and New Delhi: SAGE Publications), p. 8.

2. S. Castles and M.J. Miller (2003) The Age of Migration: International Population Movements in the Modern World (London: Palgrave Macmillan), p. 1. 
3. S.S. Friedman (2006) Migrations, diasporas, and borders. In: D. Nicholls, (Ed.), Introduction to Scholarship in Modern Languages and Literatures (New York: MLA), pp. 899-941, 906.

4. I. Ateljevic (2013) Visions of transmodernity: A new renaissance of our human history? Integral Review, 9(2), pp. 200-219 207.

5. R.M. Rodríguez Magda (2004) Transmodernidad (Barcelona: Anthropos), p. 30 .

6. M.M. Ferree (2006) Globalization and feminism: Opportunities and obstacles for activism in the global arena. In: M.M. Ferree and A.M. Tripp (Eds), Global Feminism: Transnational Women's Activism, Organizing, and Human Rights (New York and London: New York University Press), pp. 3-23 4.

7. This term, defined as: 'the simultaneous occurrence of both universalizing and particularizing tendencies in contemporary social, political, end economic systems' (Encyclopedia Britannica, accessed on 9 September 2016 at https:// global.britannica.com/topic/glocalization) originated in Japanese agriculture, and spread from the world of business, where it alludes to the expansion of multinational companies, to academic and popular discourse.

8. M. Rothberg (2009) Multidirectional Memory: Remembering the Holocaust in the Age of Decolonization (Stanford: Stanford University Press), p. 3, emphasis in original.

9. M. Silverman (2013) Palimpsestic Memory: The Holocaust and Colonialism in French and Francophone Fiction and Film (New York and Oxford: Berghahn Books), p. 23.

10. The concept of minority applied in this study follows Castles and Miller's notion that a minority is constructed through a mutual process of both Other and Selfdefinition: 'Other-definition refers to various forms of exclusion and discrimination (or racism). Self-definition has a dual character. It includes assertion and recreation of ethnic identity, centred upon pre-migration cultural symbols and practices. It also includes political mobilization against exclusion and discrimination, using cultural symbols and practices in an instrumental way.' S. Castles and M.J. Miller (2003) The Age of Migration: International Population Movements in the Modern World (London: Palgrave Macmillan), pp. 7-8.

11. S. Radstone (2011) What place is this? Transcultural memory and the locations of memory studies. Parallax, 17(4), pp. 109-123, 110.

12. K. Schramm (2011) Introduction: Landscapes of violence: memory and sacred space. History \& Memory, 23(1), pp. 5-22, 5.

13. A. Erll (2011) Travelling memory. Parallax, 17(4), pp. 4-18.

14. T. Adorno (1978) Minima moralia: Reflections from a damaged life, Trans. E.F.N. Jephcott (London: Verso); T. Adorno (1984) In: G. Adorno and R. Tiedemann (Eds), Aesthetic Theory. Trans. C. Lendhart (London: Routledge).

15. W. Benjamin (1985) One-way Street and Other Writings, Trans. E. Jephcott and K. Shorter (London: Verso); W. Benjamin (1992) The storyteller. In: W. Benjamin, Illuminations (London: Fontana Press), pp. 83-107.

16. M. O'Neill (2008) Transnational refugees: The transnational role of art? Forum: qualitative social research, 9(2), Art. 59, May 2008. Accessed on 10 October 2016 at: http://www.qualitative-research.net/index.php/fqs/article/view/403/873.

17. S. Hall (1997) Representation: Cultural Representations and Signifying Practices (London: Sage and Open University), p. 50.

18. S.L. Bloom (2010) Bridging the black hole of trauma: The evolutionary significance of the arts. Psychotherapy and Politics International, 8(3), pp. 198-212, 200-203. 
19. L.H. Nelson (2001) Damages Identities, Narrative Repair (Ithaca, NY: Cornell University Press), p. xii.

20. H. Foster (1996) The Return of the Real: The Avant-Garde at the End of the Century (London: October Books), G. Hartman (2003) Trauma within the limits of literature. European Journal of English Studies, 7(3), pp. 257-274.

21. S. Freud and J. Breuer (1991 [1893]) On the Psychical Mechanism of Hysterical Phenomena: Preliminary Communication. In: J. and A. Strachey, (Eds and trans) Studies on Hysteria (London: Penguin), pp. 53-69.

22. P. Janet (1901) The Mental State of Hystericals: A Study of Mental Stigmata and Mental Accidents, Trans. C. Rollin Corson (New York and London: G.P. Putnam's Sons).

23. C.G. Jung (1990 [1959]) In: M. Fordham and G. Adler, (Eds) The Archetypes and the Collective Unconscious. The Collected Works of Carl Jung, vol. 9.1, Trans R. C. Hull and H. Read (London: Routledge).

24. S.A. Henke (1998) Shattered Subjects: Trauma and Testimony in Women's Life-Writing (London: Macmillan), pp. xii-xiii.

25. C. Caruth (Ed.) (1995) Trauma: Explorations in Memory (Baltimore, MD and London: Johns Hopkins University Press); R. Granofsky (1995) The Trauma Novel: Contemporary Symbolic Depictions of Collective Disaster (New York: Peter Lang); R. Luckhurst (2008) The Trauma Question (London: Routledge);

A. Whitehead (2004) Trauma Fiction (Edinburgh: Edinburgh University Press).

26. D. LaCapra (2001) Writing History, Writing Trauma (Baltimore and London: The Johns Hopkins University Press), p. 41.

27. E. Levinas (1981 [1974]) Otherwise than Being: or, Beyond Essence, Trans. A. Lingis (The Hague: Martinus Nijhoff); E. Levinas (1991 [1961]) Totality and Infinity: An Essay on Exteriority. Trans. Alphonso Lingis (London: Kluwer Academic Publishers).

28. S. Onega (2014) The notion of paradigm shift and the roles of science and literature in the interpretation of reality. European Review, 22, 491-503, 498.

29. D. Attridge (2004) The Singularity of Literature (London and New York: Routledge), p. 3.

30. J.M. Ganteau (2014) vulnerable form and traumatic vulnerability: Jon McGregor's Even the Dogs. In: S. Onega and J.M. Ganteau, (Eds), Contemporary Trauma Narratives: Liminality and Ethics of Form (New York and London: Routledge), pp. 89-103, 100-101.

31. J.F. Lyotard (1979 [1984]) The Postmodern Condition: A Report on Knowledge, Trans C. Bennington (Manchester: Manchester University Press).

32. P. Tew (2007) The Contemporary British Novel (London and New York: Continuum), p. 15.

33. J.M. Ganteau (2015) The Ethics and Aesthetics of Vulnerability in Contemporary British Fiction (New York and Oxon: Routledge), p. 26.

34. A. Heilmann and M. Lewellyn (Eds) (2007) Metafiction and Metahistory in Contemporary Women's Writing (Hampshire and New York: Palgrave Macmillan), p. 3.

35. Ch. Achebe (2000) Home and Exile (Oxford: Oxford University Press), p. 79 .

36. M. Rothberg (2014) Preface: beyond Tancred and Clorinda - Trauma studies for subjects. In: G. Buelens, S. Durrant and R. Eaglestone, (Eds) The Future of Trauma Theory: Contemporary Literary and Cultural Criticism (London and New York: Routledge, Taylor and Francis Group), pp. xi-xviii, xvii. 
37. E. Figes (1986 [1970]) Patriarchal Attitudes: Women in Society (London: Virago); E. Showalter (1988 [1977]) A Literature of their Own: British Women Novelists from Brontë to Lessing (London: Virago).

38. S. Basow (1992) Gender Stereotypes and Roles (Belmont: Brooks/Cole Publishing Company); J. Butler (2006 [1990]) Gender Trouble (New York: Routledge).

39. P. Waugh (2004) Feminism and writing: The politics of culture. In: L. Marcus and P. Nicholls, (Eds), The Cambridge History of Twentieth Century of English Literature (Cambridge: Cambridge University Press), pp. 600-617, 602.

40. S. Andermahr and S. Pellicer-Ortín (2013) Trauma Narratives and Herstory (London, Basingstoke: Palgrave Macmillan), p. 9.

41. P. Hondagneu-Sotelo (2000) Feminism and migration. Annals of the American Academy, 571, pp. 107-120, 116.

42. K. Neyts (2015) Female migration, urban relocation and remaking home: Excerpts from a report. Open Democracy. Accessed on 21 February 2016 at https:// www.opendemocracy.net/womenoftheworld/female-migration-urban-relocation-andremaking-home.

43. L. Gilmore and E. Marshall (2010) Girls in crisis: Rescue and transnational feminist autobiographical resistance. Feminist Studies, 36(3), pp. 667-690.

44. M.J. Alexander (2005) Pedagogies of Crossing: Mediations on Feminism, Sexual Politics, Memories and the Sacred (Durham and London: Duke University Press).

45. M. Blackwell, L. Briggs and M. Chiu (2015) Transnational feminisms roundtable. Frontiers, 36(3), 1-25 2-3.

46. G. Anzaldúa (1987) Borderlands/La Frontera (San Francisco: Aunt Lute Books)

47. E. Sun, E. Peretz and U. Baer (2007) The Claims of Literature: A Shoshana Felman Reader (Yale: Fordham University Press), p. 1.

48. I. Grewal and C. Kaplan (1994) Scattered Hegemonies: Postmodernity and Trasnational Feminist Practices (Minneapolis and London: University of Minnesota Press), p. 21.

49. P. Boxall (2013) Twenty-First Century Fiction: A Critical Introduction (Cambridge: Cambridge University Press), p. 168.

50. T. Morrison (2007 [1987]) Beloved (London: Vintage Books), p. 21.

51. E. Domínguez-Rue (2013) History unwritten: Trauma, memory, identity and history in Toni Morrison's Beloved. In: S. Andermahr and S. Pellicer-Ortín, (Eds), Trauma Narratives and Herstory (London, Basingstoke: Palgrave Macmillan), pp. 141-152, 151.

52. Z. Smith (2001) White Teeth (London: Vintage Books), p. 193.

53. L. Gilmore (2001) The Limits of Autobiography: Trauma and Testimony (Ithaca and London: Cornell University Press).

54. S. Pellicer-Ortín (2014) Separatedness and connectedness': Generational trauma and the ethical impulse in Anne Karpf's The War After: Living with the Holocaust. In: S. Onega and J.M. Ganteau, (Eds) Contemporary Trauma Narratives: Liminality and the Ethics of Form (New York: Routledge), pp. 193-209, 194-195.

55. A. Karpf $(1996,2008)$. The War After: Living with the Holocaust (London: Minerva)

56. A. Karpf (1996) On The War After: Anne Karpf. Accessed on 18 April 2012 at http://www.faber.co.uk/article/2008/12/war-after-anne-karpf/.

57. M. Wandor (2004) At the edges of the centre; or close encounters of a Jewish kind; or the D word. In: U. Behlau and B. Retiz, (Eds), Women's Writing of the 1990s and Beyond in Great Britain and the United States (MUSE: Mainz), pp. 17-25, 23. 
58. K. Kaplan (1987) Deterritorialization: The rewriting of home and exile in western feminist discourse. Cultural Critique, 6, Special Issue The Nature and Context of Minority Discourse 187-198, 198.

59. S. Lightman (2014) Graphic Details: Jewish Women's Confessional Comics in Essays and Interviews (Jefferson, North Carolina: McFarland \& Company).

60. Gwendolyn Willow Wilson and Adrian Alphona's Ms. Marvel No Normal (2014).

61. Some telling examples may be observed on their official website: http://www. migrantas.org/web_migrantas_english.html (accessed on 22 February 2016).

62. D. Laub and D. Podell (1995) Art and trauma. International Journal of PsychoAnalysis, 76(5), 991-1005, 998.

63. A.M. Tripp (2006) The evolution of transnational feminisms: Consensus, conflict, and new dynamics. In: M.M. Ferree and A.M. Tripp, (Eds), Global Feminism: Transnational Women's Activism, Organizing, and Human Rights (London and New York: New York University Press), pp. 51-78, 51-52, emphasis added.

64. J. Berger (1992 [1989]) Miners. Exhibition catalogue. In Keeping a Rendezvous (London: Vintage), p. 9.

\section{About the Author}

Silvia Pellicer-Ortín is a Lecturer in the Department of English and German Philology, the Faculty of Education, University of Zaragoza, Spain. Her main research interests are related to contemporary narratives in English, focusing on trauma, memory and Holocaust studies, British-Jewish women writers, and feminism. She has delivered several papers and published articles on these topics in international forums such as Atlantis, CCS, Critical Engagements and Humanities. She recently published Eva Figes' Writings: A Journey through Trauma (Cambridge Scholars Publishing, 2015), and co-edited Memory Frictions in Contemporary Literature, with María Jesús Martínez-Alfaro, due in 2017 (Palgrave Macmillan). 